\title{
ECONOMICS OF SMALL SCALE COMMERCIAL BANANA FARMING IN TANGAIL DISTRICT OF BANGLADESH
}

\author{
Z.T. Munia ${ }^{1}$, S. Islam ${ }^{2}$, K. Akhi ${ }^{3}$ and M.S. Islam ${ }^{4}$ \\ Received 30 October 2019, Revised 15 December 2019, Accepted 24 December 2019, Published online 31 December 2019
}

\begin{abstract}
This study was conducted to analyze the profitability of banana farming in some selected areas of Tangail district of Bangladesh during 2015. A total of 60 samples (16 small, 19 medium and 25 large farmers) were directly interviewed using a structured questionnaire for achieving the purpose. Apart from the descriptive analysis of the socio-economic variables of the selected respondents, the benefit-cost and functional profitability analysis of banana farming were also performed. The Cobb-Douglas production function was chosen to determine the effects of various inputs on the profitability of banana. The finding of costbenefit analysis reveals that banana farming is a profitable activity in Bangladesh as the estimated cost of production was lower than the return in the selected study areas. However, the profitability differs among different farmers' group and large farmers are more profitable in banana farming than small and medium farmers. In addition, the functional analysis identifies four inputs such as the cost of human labor, manure, fertilizer and irrigation as the significant determinants of profitability of banana farming in the study area. In this study, resource use efficiency was also measured to show the efficient resource allocation to attain the goal of profit maximization which showed that human labor, seedling, manure, fertilizer, insecticides, irrigation and bamboo has inefficient use of the resources, and farmers should limit the use of these inputs. The researcher suggested some recommendations to improve the present production situation so that banana farming could be more viable and attractive commercial enterprise.
\end{abstract}

Keywords: Banana, Profitability, Cobb-Douglas Production Function, Resource Use Efficiency.

\footnotetext{
${ }^{1}$ Department of Agricultural Economics, Bangladesh Agricultural University, Mymensingh-2202, Bangladesh.

${ }^{2}$ Assistant Professor, Department of Agricultural Economics, Bangabandhu Sheikh Mujibur Rahman Agricultural University, Gazipur-1706, Bangladesh.

${ }^{3}$ Assistant Professor, Department of Agricultural Economics, Bangabandhu Sheikh Mujibur Rahman Agricultural University, Gazipur-1706, Bangladesh.

${ }^{4}$ Supervisor, Department of Agricultural Economics, Bangladesh Agricultural University, Mymensingh-2202, Bangladesh.

*Corresponding author's email: shamima@bsmrau.edu.bd (S. Islam)
}

Cite this article as: Munia, Z.T., Islam, S., Akhi, K. and Islam, M.S. 2019. Economics of small scale commercial banana farming in Tangail district of Bangladesh. Int. J. Agril. Res. Innov. Tech. 9(2): 67-75. DOI: 10.3329/ijarit.v9i2.45413.

\section{Introduction}

Bangladesh is blessed with a variety of fruits and vegetables due to tropical and subtropical climate. Among the fruit crops grown in Bangladesh, banana ranks third in terms of production by producing 0.80 million tons from 0.12 million acres of land (BBS, 2017). Banana (Musa paradisiaca, family Musaceae) is possibly world's oldest fruit, which is widely consumed both as food and medicine (Kumar et al., 2012). As a diet, banana is an opulent source of carbohydrate with 67 calories per $100 \mathrm{~g}$ fruit and is one of the most preferred and widely traded fruit across the world (Emaga et al., 2008; Kumar et al., 2012). Moreover, it is highly nutritious (Sharrock and Lustry, 2000) and is more easily digestible than many other fruits including apple (Mohapatra et al., 2010). Apart from the nutritional value banana is also one of the economically important food crops grown both in homestead and commercial farms 
(Ahmed, 1984). Banana is considered as one of the finest fruits and the most important in terms of food value, food security, food availability and above all, it is a crop that has a positive impact on increasing household income and alleviating poverty (Fonsah et al., 2018). In addition, banana cultivation had positive impact on farmers' livelihood and it places a valuable position among the fruits of Bangladesh not only for its highest production but also for its increasing popularity to many farmers as an economic crop (Tabassum et al., 2018). In order to meet the demand for fruits and vegetables for the increasing population, the government of Bangladesh has given much more emphasis on year-round crop like banana cultivation to achieve overall selfsufficiency. The foremost banana growing areas are Tangail, Rangamati, Barisal, Rangpur, Dinajpur, Noakhali, Faridpur, and Khulna. There are a number of banana cultivars among them, BARI Kola-1, Amritsagar, Sabri, Champa and Kabri are the commercial cultivars in Bangladesh (Mukul and Rahman, 2013).

The available literature review suggests that some studies (Prodhan et al., 2017, Kamal et al., 2014a; Rahman, 2006) were conducted on the socioeconomic characteristics of banana growers, their problems, etc. while there are few studies (Islam et al., 2018; Kamal et al., 2014b, Mukul and Rahman, 2013, Parvin et al., 2013) conducted on profitability of banana production in Bangladesh. However, most of these studies analyzed the profitability only by descriptive analysis and not by a combination of both descriptive and econometric analysis except Mukul and Rahman (2013). Until recently, little efforts have been made to measure the factors influencing economic returns of banana production. Given this backdrop, the present study attempts to evaluate the economics of small-scale commercial banana farming in Tangail district of Bangladesh. It is expected that the systematic calculation of costs and returns, as well as the profitability of banana under this study, will add up knowledge to the researchers, policymakers as well as other interested parties who will conduct farther study on banana farming in Bangladesh. Specifically, the study aims to: (i) assess the financial profitability of banana production and (ii) determine the factors influencing the returns of banana production.

\section{Materials and Methods}

\section{Sampling technique and data collection}

Considering the objectives of the study Madhupur upazila of Tangail district of Bangladesh was selected purposively as the study area. Four villages namely Joynagacha, Gopinathpur, Sholakudi and Vobaniteki were covered for collecting necessary information for the study. A total of 60 farmers including 16 small, 19 medium and 25 large farmers, were selected by stratified random sampling. In this case, the farms were categorized by total land as small farmers (having land 0.40-1.01 hectares), medium farmers (having land 1.01-3.03 hectares) and large farmers (3.03 hectares and above) (BBS, 2017). The researchers collected necessary primary data of banana growers through questionnaire interview with a structured questionnaire during the period of February to April, 2015.

\section{Analytical method}

The collected data was analyzed on the basis of the objectives of the study by using descriptive statistics, mathematical and statistical analysis. Descriptive statistics were used to represent the socio-economic characteristics of the respondents.

\section{Mathematical analysis}

Mathematical analysis includes the profitability of banana production, which was calculated in terms of gross return, gross margin, net return, and benefit cost ratio (BCR).

\section{Gross return}

Gross return (GR) was calculated by multiplying the total volume of output of an enterprise by the average price in the harvesting period (Dillon and Hardaker, 1993).

Gross return, GR $=\Sigma \mathrm{QP} \ldots$ (1)

Where, $\mathrm{GR}=$ Gross return from product (BDT/ha); $\mathrm{Q}=$ Quantity of the product; $\mathrm{P}=$ Average price of the product (BDT/ha).

\section{Gross margin}

Gross margin (GM) of farming enterprise is its output less the variable costs attributed to it (Barnard and Nix, 1999).

$\mathrm{GM}=\mathrm{GR}-\mathrm{TVC} \ldots$ (2)

Where, GM = Gross margin $(\mathrm{BDT} / \mathrm{ha}) ; \mathrm{GR}=$ Gross return (BDT/ha); and TVC = Total variable cost (BDT/ha).

\section{Net return}

Net return was calculated by deducting total costs from gross return as shown in the equation 3 .

Net Return, $\mathrm{NR}=\Sigma(\mathrm{GR}-\mathrm{TC}) \ldots$ (3)

Where, GR $=$ Gross return from product (BDT/ha); $\mathrm{TC}=$ Total cost (BDT/ha). 


\section{Benefit cost ratio (BCR)}

The BCR is a relative measure, which is used to compare benefit per unit of cost. The BCR estimated as a ratio of gross returns and gross costs.

Benefit cost ratio, $(\mathrm{BCR})=$ Gross return/ Total cost ... (4)

\section{Statistical analysis}

Cobb-Douglas production function

In order to estimate the effects of key variables in banana production, the Cobb-Douglas form of production function was used. The specification of the Cobb-Douglas production function for banana production was as follows (Nerlove, 1965):

$$
Y_{i}=a X_{1}^{b_{1}} X_{2}^{b_{2}} X_{3}^{b_{3}} X_{4}^{b_{4}} X_{5}^{b_{5}} X_{6}^{b_{6}} X_{7}^{b_{7}} e^{u_{i}}
$$

The Cobb-Douglas production function was transformed into following logarithmic form so that it could be estimated by the Ordinary Least Squares (OLS) method:

$\ln Y_{i}=\ln a+b_{1} \ln X_{1}+b_{2} \ln X_{2}+b_{3} \ln X_{3}+$ $b_{4} \ln X_{4}+b_{5} \ln X_{5}+b_{6} \ln X_{6}+b_{7} \ln X_{7}+u_{i}$

Where,

ln = Natural logarithm, $Y_{i}=$ gross return (BDT/ha), $X_{1}=$ human labor cost, (BDT/ha) $X_{2}=$ seedlings/suckers cost (BDT/ha), $X_{3}=$ fertilizer cost (BDT/ha), $X_{4}=$ manure cost (BDT/ha), $X_{5}=$ insecticides cost $(\mathrm{BDT} / \mathrm{ha}), X_{6}=$ irrigation cost (BDT/ha), $X_{7}=$ bamboo cost (BDT/ha), $a=$ constant, $b_{1}, b_{2}, \ldots . ., b_{7}=$ production coefficient of the respective input variables to be estimated, $u_{i}$ $=$ Error term.

\section{Measuring resource use efficiency}

To accomplish the resource use efficiency, the MVP of a particular resource represents the total output in value terms resulting from an addition of one unit of those resources while other inputs are held constant. The most reliable estimate of MVP is obtained by taking resource $\left(\mathrm{X}_{\mathrm{i}}\right)$ as well as gross return $(\mathrm{Y})$ at their geometric means. Since the seven variables of the regression model were measured in monetary value, the slope of coefficients of those explanatory variables in the function represented the MVPs which were calculated by multiplying the production coefficient of given resources with the ratio of geometric mean $(\mathrm{GM})$ of the given resources, i.e., $\operatorname{Ln} \mathrm{Y}=\ln \mathrm{a}+\mathrm{b}_{\mathrm{i}} \ln \mathrm{X}_{\mathrm{i}}$

$\frac{d y}{d x}=b_{i} \frac{Y}{X_{i}}$

Therefore,

$$
\operatorname{MVP}\left(\mathrm{X}_{\mathrm{i}}\right)=b_{i} \frac{\bar{Y}(G M)}{\overline{X \imath}(G M)}
$$

Where,

$\bar{Y}=$ Mean value of gross return (Geometric mean);

$\bar{X}_{\mathrm{i}}=$ Mean value of $\mathrm{i}^{\text {th }}$ variable input (Geometric mean); $i=1,2,3,4,5,6$ and 7 ;

$\mathrm{GM}=$ Geometric mean; and

$\mathrm{dy} / \mathrm{dx}=$ Slope of production function as well as MVP of input.

The optimum use of a particular input would be indicated by the condition of equality of MVP and MFC. If the ratio of MVP and MFC is greater than 1 , the resource is sub-optimally used and the gross return could be increased by using more of the resource. If it is less than 1 , the resource is over used and the excess use of resource should be decreased to minimize the loss.

\section{Results and Discussion}

\section{Socio-economic characteristics of the sample farmers}

Socio-economic characteristics illustrate the wide ranges of interrelated social attributes of the farmers, which largely influences their economic activities, living condition and decision making process. Table 1 indicates that the majority of the farmers were middle aged in the study area (56.67\%). This group of respondents is expected to earn a higher profit due to being energetic and productive in the field. The educational status of the selected banana growers shows that most of the selected farmers were educated up to primary level (58.33\%) only, it indicates that farmers in the study area are in need of certain knowledge of farming and technology. Similar results were obtained by Kamal et al. (2014b). 
Table 1. Socio-economic profile of the banana growers.

\begin{tabular}{|c|c|c|c|c|}
\hline Particulars & Small & Medium & Large & All \\
\hline \multicolumn{5}{|l|}{ Age } \\
\hline Young (18 to 35 ) & $5(31.25)$ & $5(26.32)$ & $8(32.00)$ & $18(30.00)$ \\
\hline Middle aged (36 to 50) & $10(62.50)$ & $10(52.63)$ & $14(56.00)$ & $34(56.67)$ \\
\hline Old (above 50) & $1(6.25)$ & $4(21.06)$ & $3(12.00)$ & $8(13.33)$ \\
\hline \multicolumn{5}{|l|}{ Educational status } \\
\hline Illiterate & $2(12.50)$ & o (o.0o) & o (o.oo) & $2(3.33)$ \\
\hline Primary & $9(56.25)$ & $12(63.16)$ & $14(56.00)$ & $35(58.33)$ \\
\hline Secondary & $3(18.75)$ & $3(15.79)$ & $3(12.00)$ & $9(15.00)$ \\
\hline Higher secondary & $1(6.25)$ & $3(15.79)$ & $4(16.00)$ & $8(13.34)$ \\
\hline Graduate & $1(6.25)$ & $1(5.26)$ & $4(16.00)$ & $6(10.00)$ \\
\hline \multicolumn{5}{|l|}{ Occupational Status } \\
\hline Agriculture & $11(68.75)$ & $13(68.42)$ & $17(68.00)$ & $41(68.33)$ \\
\hline Agriculture and business & $3(18.75)$ & $5(26.31)$ & $5(20.00)$ & $13(21.67)$ \\
\hline Agriculture an & $2(12.50)$ & $1(5.27)$ & $3(12.00)$ & $6(10.00)$ \\
\hline \multicolumn{5}{|l|}{ Land holding } \\
\hline Owned land & $0.38(69.56)$ & $0.88(77.19)$ & $2.44(73.93)$ & $1.26(77.77)$ \\
\hline Leased in & $0.16(23.18)$ & $0.22(19.29)$ & $0.84(25.45)$ & $0.34(20.98)$ \\
\hline Leased out & $0.01(1.44)$ & $0.05(4.38)$ & $0.08(2.42)$ & $0.06(3.70)$ \\
\hline Homestead area & $0.06(8.70)$ & $0.08(7.01)$ & $0.09(2.72)$ & $0.07(4.32)$ \\
\hline Mortgaged in & $0.00(0.00)$ & $0.02(1.75)$ & $0.04(1.21)$ & $0.03(1.85)$ \\
\hline Mortgaged out & $0.00(0.00)$ & $0.01(0.87)$ & $0.03(0.90)$ & $0.02(1.23)$ \\
\hline Area under banana & $0.61(88.41)$ & $0.98(85.96)$ & $3.15(95.45)$ & $1.48(91.35)$ \\
\hline \multicolumn{5}{|l|}{ Farming Experience } \\
\hline $1-5$ years & $2(12.50)$ & $6(31.57)$ & $3(12.00)$ & $11(18.33)$ \\
\hline 5-10 years & $11(68.75)$ & $9(47.37)$ & $13(52.00)$ & $33(55.00)$ \\
\hline Above 10 & $3(18.75)$ & $4(21.05)$ & $9(36.00)$ & $16(26.67)$ \\
\hline \multicolumn{5}{|l|}{ Annual Income } \\
\hline Farm income & $198460(85.93)$ & $213990(84.48)$ & $219850(84.34)$ & $207905(85.30)$ \\
\hline Non-farm income & $32500(14.07)$ & $39300(15.51)$ & $40800(15.66)$ & $35800(14.69)$ \\
\hline
\end{tabular}

Source: Author's estimation based on field survey, 2015.

N.B.: Values in parenthesis indicate the percentage of total.

In the study area agriculture was found to be the inherent and single major occupation of almost all the farmers. Table 1 also revealed that considering all farmers the area under banana farming was $91.35 \%$ of the total land. Farming experience is an important socio-economic characteristic, which affect the production of banana. It is evident from the table that considering all farmers, $18.33 \%$ of sampled farmers fell in group of 1-5 years of farming experience. Income is the most important indicator of the socio-economic status of the people living in rural areas of Bangladesh. The average annual household income of banana farmers was found to be BDT 243705 of which $85.30 \%$ of total income from farm activities.

\section{Cost and return of banana}

When the cost of inputs deducted from the value of output, then it expresses the profitability analysis. Estimation of cost was exclusively necessary for enterprise costing and subsequently determining the viability of the enterprise from the view point of producers. The farmers used different inputs for banana production. Cost of using these inputs are discussed below:

\section{Estimation of variable cost}

Variable costs are the costs of using the variable inputs. These costs vary with the level of production. There are some necessary inputs like seed, human labor, fertilizer, irrigation etc. These costs considered as variable costs of banana is discussed under the following headings.

\section{Human labor cost}

Human labor is the most important and largely used input for producing banana. It is required for different operations i.e., land preparation, sucker planting, weeding and harvesting of banana was computed in terms of man-days. Table 1 reveals that considering all farmers the cost of human labor for banana production was calculated BDT 82800 per hectare, which covered $30.33 \%$ of the total cost. 


\section{Power tiller cost}

Power tiller was mainly used for land preparation. It appears that, the cost of power tiller for banana production was higher for small farmers than those of medium and large farmers, respectively (Table 2).

\section{Cost of seedling/sucker}

In the study area, many farmers used purchased suckers for producing banana. Per hectare total cost of suckers for banana production were calculated at BDT 9554, 9282 and 9377 for small, medium and large farmers, respectively (Table 2).

\section{Cost of manure}

In the study area, farmers used cowdung as manure for producing banana. Thus, the overall cost of manure was calculated at BDT 8427 per hectare in banana farming.

\section{Cost offertilizers}

Application of recommended doses of fertilizer is important for crop production. In the study area, farmers used mainly five types of fertilizer namely Urea, TSP (Triple Super Phosphate), MP
(Muriate of Potash), Gypsum and Zinc sulphate. The overall fertilizer cost for banana production was calculated BDT 49095 per hectare, which covered $17.98 \%$ of total cost.

\section{Cost of insecticides}

Farmers used different kinds of insecticides to protect their banana in the field from various insects and pests. Table 2 showed that the overall insecticide costs for banana production was calculated BDT 15018 per hectare, which covered the $5.50 \%$ of the average total cost.

\section{Cost of irrigation}

In the study area, the all farmers uses irrigation for their cultivation. Per hectare costs of irrigation for banana production were almost similar (i.e. BDT 10798, 10111 and 1000o) for small, medium and large farmers, respectively.

\section{Cost of bamboo}

Bamboo is a very important input in banana production. The average per hectare cost of bamboo for banana production was calculated BDT 18647 per hectare, which covered the $6.84 \%$ of the total cost (Table 2).

Table 2. Cost of banana production (BDT/ha).

\begin{tabular}{|c|c|c|c|c|}
\hline Cost items & Small farmers & $\begin{array}{l}\text { Medium } \\
\text { farmers }\end{array}$ & Large farmers & All farmers \\
\hline \multicolumn{5}{|l|}{ A. Variable Cost } \\
\hline Human labor & $84300(30.71)$ & $86400(31.37)$ & 78900 (29.11) & $82800(30.33)$ \\
\hline Power tiller & $7608(2.77)$ & $7130(2.59)$ & $7278(2.69)$ & $7630(2.79)$ \\
\hline Seedling/Sucker & $9554(3.48)$ & $9282(3.37)$ & $9377(3.45)$ & $9394(3.44)$ \\
\hline Manure & $8320(3.03)$ & $8723(3.17)$ & $8270(3.05)$ & 8427 (3.09) \\
\hline Fertilizer: Urea & 15248 & 15232 & 15392 & 15296 \\
\hline TSP & 18546 & 17006 & 20240 & 18766 \\
\hline MP & 8865 & 9285 & 9420 & 9225 \\
\hline Gypsum & 1800 & 1860 & 1872 & 1848 \\
\hline $\mathrm{ZnSO}_{4}$ & 4320 & 3780 & 4140 & 3960 \\
\hline Total Fertilizer Cost & $48779(17.77)$ & $47163(17.12)$ & $51064(18.84)$ & 49095 (17.98) \\
\hline Insecticides & $15347(5.59)$ & $15565(5.65)$ & $15231(5.62)$ & $15018(5 \cdot 50)$ \\
\hline Irrigation & $10798(3.93)$ & $10111(3.67)$ & $10000(3.69)$ & $10248(3.75)$ \\
\hline Bamboo & $18948(6.90)$ & $18974(6.89)$ & $18204(6.72)$ & $18647(6.84)$ \\
\hline Total Variable Cost & $203654(74.18)$ & $203348(73.83)$ & $198324(73.17)$ & $2012599(73.72)$ \\
\hline \multicolumn{5}{|l|}{ B. Fixed Cost } \\
\hline Land use cost & 52394 (19.09) & $52394(19.02)$ & $52394(19.33)$ & 52394 (19.19) \\
\hline $\begin{array}{l}\text { Interest on operating } \\
\text { capital }\end{array}$ & $11200(4.08)$ & $11184(4.06)$ & $10908(4.02)$ & $11069(4.05)$ \\
\hline $\begin{array}{l}\text { Depreciation on farm } \\
\text { implements }\end{array}$ & $7200(2.62)$ & 8500 (3.09) & $9400(3.47)$ & $8300(3.04)$ \\
\hline Total Fixed Cost & $70794(25 \cdot 79)$ & 72078 (26.17) & 72702 (26.82) & 717639 (26.28) \\
\hline C. Gross Cost $(\mathrm{A}+\mathrm{B})$ & 274448 (100.00) & 275426 (100.00) & 271026 (100.00) & 273022 (100.00) \\
\hline
\end{tabular}

Source: Author's estimation based on field survey, 2015.

N.B.: Values in parenthesis indicate the percentage of total cost. 


\section{Estimation of fixed cost}

Fixed costs are costs, which do not change in magnitude as the amount of output changes and are incurred even when production is not undertaken. The interest on operating capital, land use cost and depreciation cost on farm equipment were considered as fixed cost of banana production in this study.

\section{Interest on operating capital}

Interest on operating cost includes variable costs in the production of banana for a period of 6 months production period. The interest actually means the average operating costs over the time period as all the costs were not incurred at the same time; rather these were used throughout the production period from beginning to the end. The interest on operating capital for different categories of farmers, such as small, medium and large were estimated at BDT 11200, 11184 and 10908, respectively (Table 2). The cost was calculated at the rate of $11 \%$ per annum.

\section{Land use cost}

The seasonal rental cost of land was treated as land use cost for the farmers. Land use cost was calculated on the basis of lease value of per hectare land for cropping period 12 months. This amount was BDT 52394 for all categories of farmers, which covered $19.19 \%$ of the total cost.

\section{Depreciation on farm implements}

Depreciation on farm implements was estimated at BDT 7200, 8500 and 9400 per hectare, which represented 2.62, 3.09 and $3.47 \%$ of total cost for small, medium and large farmers.

\section{Gross Cost}

Gross cost was calculated by adding all costs of variable inputs and fixed inputs. In the present study, per hectare gross costs of producing banana were BDT 274448, 275426 and 271026 for small, medium and large farmers, respectively and average gross cost of producing banana was
BDT 273022 (Table 2). As a result, it found that highest and lowest cost per hectare occurred in medium farmers and large farmers, respectively.

\section{Gross return}

Per hectare gross return was calculated by multiplying the total amount of yield by their respective per unit farm gate price of banana. Per hectare gross returns of banana were BDT 454150, 467245, 482226 for small, medium and large farmers, respectively (Table 3 ). The average gross return of banana was BDT 468200 . It may be noted that here the price of banana was reported to be BDT 200 per bunch which was the average farm gate price in the study area.

\section{Gross margin}

Gross margin is obtained by deducting variable cost from gross return. Average per hectare gross margin of producing banana was calculated at BDT 266941.

\section{Net return}

Net return was calculated by deducting gross cost from the gross return. Per hectare net returns of banana were BDT 179702, 191819 and 211200 for small, medium and large farmers, respectively which indicates that net return from banana production was highest for large farmers.

\section{Benefit- cost ratio (undiscounted)}

The final economic measure is the calculation of BCR (undiscounted) which is generally used to compare benefits per unit of cost. The BCR is generally calculated as the ratio of total returns and total cost, which is equal to 1.71 for all farmers in the study areas during 2015. It implies that BDT 1.71 would be earned by investing BDT 1.00 on banana farming, thereby, it indicates that banana farming is a profitable business. However, this estimation also differs among the farmer's groups by $1.65, \quad 1.70$ and 1.78 respectively. This results also match with the findings of Islam et al. (2018) and Kamal et al. (2014a)

Table 3. Comparative economic statement of profitability of banana production under different categories of farmers (unit/hectare).

\begin{tabular}{|l|c|c|c|c|}
\hline Measuring criteria & Small farmers & Medium farmers & Large farmers & All farmers \\
\hline Gross return (BDT/ha) & 454150 & 467245 & 482226 & 468200 \\
\hline Gross cost (BDT/ha) & 274448 & 275426 & 271026 & 273022 \\
\hline Gross margin (BDT/ha) & 250496 & 263897 & 283902 & 266941 \\
\hline Net return (BDT/ha) & 179702 & 191819 & 211200 & 195178 \\
\hline BCR (undiscounted) & 1.65 & 1.70 & 1.78 & 1.71 \\
\hline
\end{tabular}

Source: Author's estimation, 2015 
From the above discussion, it is easy to understand about the different cost items and their application doses in the different categories of farmers regarding of returns per hectare banana farming. All the figures (gross return, gross margin and net return) were noticeably larger for the large farmers than small and medium farmers (Table 3). It was also observed that BCR of large farmers was the highest among different farm categories. The average BCR of all categories of farmers was 1.71, which revealed that banana farming is a profitable business and the large farmers achieved higher level of profit per hectare of banana production than the medium and small farmers.

\section{Factors influencing gross return from banana production}

This part has been made to identify and measure the effects of the factors of production on gross return of banana production in the framework of production function analysis. For this purpose, Cobb-Douglas production function model has been chosen to estimate the effects of selected inputs on banana production. Efforts have been made in this section to make a functional analysis of banana production.

Empirical results of Cobb-Douglas production function

Estimated values of co-efficient and related statistics of Cobb-Douglas production function model for banana production are shown in Table 4. Seven explanatory variables were taken into consideration for production function analysis of the farmers' efficiency in banana production.

\section{Functional relationship}

The estimated production function for banana was:

$\mathrm{LnY}=13.493+0.075 \mathrm{X}_{1}+0.008 \mathrm{X}_{2}+0.156 \mathrm{X}_{3}+$ $0.067 \mathrm{X}_{4}+0.174 \mathrm{X}_{5}-0.042 \mathrm{X}_{6}+0.264 \mathrm{X}_{7}$

\section{Explanation of explanatory variables}

\section{Human labor Cost $\left(X_{1}\right)$}

It is observed from Table 4 that the regression coefficient of human labor cost was 0.075 , which was positive and significant at 5 percent level. It implies that 1 percent increase of human labor cost keeping other factors constant, would increase the gross return by 0.075 percent.

\section{Seedling/sucker cost $\left(X_{2}\right)$}

The coefficient of sucker cost was 0.008 , which was positive but statistically insignificant. It implies that 1 percent increase of seedling cost, remaining other factors constant, would increase the gross return by 0.008 percent. The possible cause of this insignificancy might be the irrational use of seedling for producing banana.

\section{Manure cost $\left(X_{3}\right)$}

It can be seen from Table 4 that regression coefficient of manure cost was 0.156 , which was positive and significant at 1 percent level. This implies that an increase in 1 percent of manure cost, remaining other factors constant, would result in an increase in the gross return by 0.156 percent.

Table 4. Estimated values of coefficient and related statistics of banana production.

\begin{tabular}{|l|c|c|c|}
\hline Explanatory variables & Estimated Coefficient & Standard Error & t-value \\
\hline Intercepts & 13.493 & 1.418 & 9.515 \\
\hline Human labor cost $\left(\mathrm{X}_{1}\right)$ & $0.075^{* *}$ & 0.031 & 2.450 \\
\hline Seedling cost $\left(\mathrm{X}_{2}\right)$ & 0.008 & 0.086 & 0.093 \\
\hline Manure cost $\left(\mathrm{X}_{3}\right)$ & $0.156^{* * *}$ & 0.046 & 3.412 \\
\hline Fertilizer cost $\left(\mathrm{X}_{4}\right)$ & $0.067^{* *}$ & 0.031 & 2.187 \\
\hline Irrigation cost $\left(\mathrm{X}_{5}\right)$ & $0.174^{* * *}$ & 0.054 & 3.226 \\
\hline Insecticides cost $\left(\mathrm{X}_{6}\right)$ & -0.042 & 0.032 & -1.327 \\
\hline Bamboo cost $\left(\mathrm{X}_{7}\right)$ & 0.264 & 0.177 & 1.485 \\
\hline R2 & & 0.654 & \\
\hline F-value & & $18.067^{* * *}$ & \\
\hline Returns to scale $\left(\sum \mathrm{bi}\right)$ & & 0.702 & \\
\hline
\end{tabular}

Source: Author's estimation, 2015

Note: ${ }^{* * *}$ Significant at 1 percent level ** Significant at 5 percent level 


\section{Fertilizer cost $\left(X_{4}\right)$}

The coefficient of fertilizer cost was 0.067 , which was positive and significant at 5 percent level. This implies that an increase in 1 percent of fertilizer cost, other factors holding constant, would result in an increase in the gross return by 0.067 percent.

\section{Irrigation cost $\left(X_{5}\right)$}

The regression coefficient of irrigation cost was 0.174 , which was positive and significant at 1 percent level indicating that 1 percent increase of irrigation cost, keeping other factors constant, would increase the gross return by 0.174 percent.

\section{Insecticides cost $\left(X_{6}\right)$}

The coefficient of insecticides cost was 0.042 which was negative and not significant which indicates that an increase in 1 percent of insecticides cost, remaining other factors constant, would decrease the gross return by 0.042 percent. The possible cause of this insignificancy might be the inappropriate use of insecticides for producing banana.

\section{Bamboo cost $\left(X_{7}\right)$}

It can be seen that the regression coefficients of bamboo cost was 0.264 , which was positive and not significant. This implies that an increase in 1 percent of bamboo cost, remaining other factors constant, would result in an increase in the gross return by 0.264 percent. This might be occurred due to the irrational use of bamboo for producing banana.

Bathan et al. (2010) supported the findings slightly by stating that labor and fertilizer has significant effect on banana yield.

\section{Overall performance of the model}

Value of $R^{2}$

The value of the coefficient of multiple determinations $\left(\mathrm{R}^{2}\right)$ was 0.654 , which indicates that about 65 percent of variations in gross return from banana production can be explained by the explanatory variables, which were included in the model (Table 4).

\section{Goodness of fit (F-value)}

The F-value for banana production was 18.067, which was significant at one percent probability level implying that the variation in gross return depends mainly upon the explanatory variables included in the model (Table 4).

\section{Returns to scale ( $\Sigma b i)$}

The summation of all the regression coefficients or production elasticity's of the estimated model gives information about the returns to scale, that is, in response of output to a proportionate change in all inputs. The sum of all the production coefficients of the equations for banana production was 0.702 . This indicates that the production function exhibited decreasing returns to scale in banana production; implying that if all the inputs specified in the function are increased by 1 percent income will increase by 0.702 percent.

\section{Resource use efficiency}

Table 5 shows that for banana farmers, the ratios of MVP and MFC for human labor, seedling, manure, fertilizer, irrigation, insecticides and bamboo cost were $0.001,0.128,0.260,0.012$, $0.026,-0.016$ and 0.630 , respectively. All these ratios are less than 1, which indicated inefficient use of the resources, and farmers should limit the use of these inputs. The ratio of MVP and MFC of insecticides cost was negative, which indicated that farmers might have made excessive use of this input.

Table 5. Ratio of marginal value products (MVPs) and marginal factor cost (MFCs) of different inputs incurred in producing banana.

\begin{tabular}{|lccccc|}
\hline \multicolumn{1}{c}{ Variables } & Geometric mean & Coefficient & MVPs & MFC & MVP/MFC \\
\hline Intercepts $(\mathrm{Y})$ & 444590 & 1.418 & & & \\
\hline Human labor cost $\left(\mathrm{X}_{1}\right)$ & 82470 & 0.075 & 0.404 & 300.00 & 0.001 \\
\hline Seedling cost $\left(\mathrm{X}_{2}\right)$ & 9270 & 0.008 & 0.384 & 3.00 & 0.128 \\
\hline Manure cost $\left(\mathrm{X}_{3}\right)$ & 8308 & 0.156 & 8.348 & 32.00 & 0.260 \\
\hline Fertilizer cost $\left(\mathrm{X}_{4}\right)$ & 49053 & 0.067 & 0.607 & 50.00 & 0.012 \\
\hline Irrigation cost $\left(\mathrm{X}_{5}\right)$ & 10210 & 0.174 & 7.571 & 290.00 & 0.026 \\
\hline Insecticides cost $\left(\mathrm{X}_{6}\right)$ & 14997 & -0.042 & -1.242 & 75.00 & -0.016 \\
\hline Bamboo cost $\left(\mathrm{X}_{7}\right)$ & 18614 & 0.264 & 6.304 & 10.00 & 0.630 \\
\hline
\end{tabular}

Source: Author's estimation, 2015

\section{Conclusions and Policy Recommendations}

Ensuring food and nutritional security and alleviating poverty is the prime concern of the present government. The Sustainable Development Goals (SDG) has reemphasized on the need of building more dependable food security system with increased productivity. Therefore, it is necessary to generate more diversified food with greater shares of fruit production. The findings of the study reveal that commercial banana farming is a profitable business in Bangladesh. However, the level of profit is significantly higher for large farmers than small and medium farmers. The functional analysis reveals that different factors determine the level of profit from banana farming. Among them, human labor, fertilizer, insecticides and 
irrigation had momentous impact to increase banana production, but the costs of these inputs are very lofty and farmers in the study area were not well known about the application of inputs in right time with right dose. Even though the government has subsidized the fertilizer price, whether there is the timely procurement of such services by the needy farmers or not should be monitored through different ministries and departments. In addition, the government can maintain collaboration with different private and research organizations so that they can come up with better and affordable technology for the banana farmers. Extension department can also play a role in providing training on modern technology use and strengthen the field demonstration process to suggest a better combination of input use for higher return. If modern inputs and production technology can be made available to farmers in time, yield and production of banana may be increased which can help the farmers to increase income and improve livelihood conditions. Moreover, as banana is a capital demanding crop, institutional credit facilities should, therefore, be made available for all banana farmers on easy terms and conditions and adequate amount. To control the price fluctuation and ensure fair price to the growers, it is also necessary to have government intervention in banana marketing. Thus, well planned, and management training in accordance with their problems can lead to them to increase farm production and income from banana farming. If proper remedial measures could be taken, banana farming could be a more viable and attractive commercial enterprise.

\section{References}

Ahmed, K. 1984. Gardener's Book on Production and Nutrition. $1^{\text {st }}$ Edition. Mumtaj Kamal, Dhaka, Bangladesh. 448p.

Barnard, C.S. and Nix, J.S. 1999. Farm Planning and Control, Cambridge University Press. 6oop.

Bathan, M.B., Flordeliza, A. and Lantican, F.A. 2010. Factors Affecting Yield Performance of Banana Farms in Oriental Mindoro. Philippines J. ISSAAS. 16(1): 110-120.

BBS. 2017. Yearbook of agricultural statistics of Bangladesh. Bangladesh Bureau of Statistics, Ministry of Planning, Government of the People's Republic of Bangladesh, Dhaka.

Dillon, J.L. and Hardaker, J.B. 1993. Farm management research for small farmer development. FAO, Rome, Italy. 313p.

Emaga, T.H., Andrianaivo, R.H., Wathelet, B., Tchango, J.T. and Paquot, M. 2008. Effects of the stage of maturation and varieties on the chemical composition of banana and plantain peels. Food Chem. 103: 590-600.
Fonsah, E.G., Tertuliano, M., Manower, T., Chattapadhya, S., Hussain, A., Islam, S., Islam, M.S., Uddin, M.J., Amin, A.S. and Amin, B.A. 2018. Survey of Agricultural Value Chain: A Case Study of Bangladesh Banana Industry. J. Agric. Env. Sci. 7(1): 141-148.

Islam, M.A., Rahman, M.A. and Saha, J.K. 2018. Profitability of banana cultivation under agricultural credit in Narsingdi district of Bangladesh. Fund. Appl. Agric. 3(3): 525530.

Kamal, M.S., Ali, M.A. and Alam F.M. 2014a. Cost and Return Analysis of Banana Cultivation under Institutional Loan in Bogra, Bangladesh. Int. J. Nat. Soc. Sci. 2(1): 19-27.

Kamal, M.S., Ali, M.A. and Alam F.M. 2014b. Socio-economic status and problems of banana growers in Bangladesh, Int. J. Nat. Soc.Sci. 1(1): 91-99.

Kumar, K.P.S., Bhowmik, D., Duraivel, S. and Umadevi, M. 2012. Traditional and Medicinal Uses of Banana. J. Pharma. Phytochem. 1(3): 51-63.

Mohapatra, D., Mishra, S. and Sutar, N. 2010. Banana and its by-product utilization: an overview. J. Sci. Indust. Res. 69: 323-329.

Mukul, A.Z.A. and Rahman, M.A. 2013. Production and profitability of banana in Bangladesh-an economic analysis. Int. $J$. Econ. Fin. Manage. Sci. 1(3): 159-165.

Nerlove, M. 1965. Estimation and Identification of Cobb-Douglas Production Functions. $1^{\text {st }}$ Edn., Rand McNally and Company. p. 193.

Parvin, M.M., Islam, M.N., Islam, F. and Habibullah, M. 2013. An Analysis of Cost of Production of Banana and Profitability at Narsingdi and Gazipur District in Bangladesh. Int. J. Res. Comm. IT Manage. 3(5): 113-118.

Prodhan, A.Z.M.S, Sarker, M.N.I, Sultana, A. and Islam, M.S. 2017. Knowledge, adoption and attitude on banana cultivation technology of the banana growers of Bangladesh. Int. $J$. Hort. Sci. Orn. Plants. 3(1): 047-052.

Rahman, M.H. 2006. Constraints Faced by the Banana Growers of Sonargaon Upazila under Narayanganj District. Department of Agricultural Extension \& Information system, Sher-E-Bangla Agricultural University, Dhaka-1207.

Sharrock, S. and Lustry, C. 2000. Nutritive value of banana, in INIBAP Annual Report (INIBAP, Montpellier, France). pp. 28- 31.

Tabassum, P., Khan, S.A.K.U., Siddiqua, M. and Sultana, S. 2018. Effect of guava leaf and lemon extracts on postharvest quality and shelf life of banana cv. Sabri (Musa sapientum L.). J. Bangladesh Agril. Univ. 16(3): 337-342. 